\title{
Fast Food Trend Analysis by Evaluating Factors Leading to Customer Satisfaction
}

\author{
Mahnoor Farooqui \\ Greenwich University, Karachi \\ Dr. S Khuram Khan Alwi \\ Associate Professor, Greenwich University, Karachi
}

\begin{abstract}
A fast food restaurant is a growing business and with the time evolving the pattern of eating habits is changing. Therefore, many people have started opting for fast food which is an appealing phenomenon for them. This research is conducted to evaluate the pattern of fast food and the customer satisfaction encompassing various factors. The analysis of the customer satisfaction encompasses independent variables which leads to consumer satisfaction and showcases the fast food trend. It is Karachi centric; target sample is from South Urban Region by the customers. The variables of this study are Quality of Service, Pricing, Ambiance and Quality of Food which are considered as independent. Age and Gender are part of Demographics. According to the IBIS World report on "Industry Market Research Report 2018", the Global Food Industry has grown over the period of five years despite the change in factors such as consumer tastes and a recovering global economy. With the increase in disposable income the spending increased by the consumers on luxuries such as dinning out. In result of this the fast food operators started to gain benefits by providing full-service restaurants. The trend of Five years revealed growth by $3.5 \%$ in the Global Fast Food industry by generating revenue of $\$ 668$ bn in 2018 (IBISWORLD 2018). Since the trend of five years revealed the growth in fast food restaurant chains similarly this research has revealed the trend of fast food restaurant in Karachi Urban South region. McDonalds and KFC are the most preferred fast food chains because their customers are satisfied with the ambiance, pricing and quality of food which drives them to opt for the particular restaurant. For the results generation regression analysis have been applied which revealed significance of three independent variables and the interferential and descriptive analysis have also been implied.
\end{abstract}

Keywords: customer satisfaction, price, quality of food, and ambiance

DOI: $10.7176 / \mathrm{JMCR} / 55-06$

Publication date: April $30^{\text {th }} 2019$

\section{Background of the Study}

Customer satisfaction is one of the foremost concepts to measure the performance of a business. There is a strong link between retaining a customer and customer satisfaction for analyzing the success of a business. In past ample of studies were conducted on customer satisfaction targeting the developed countries such as America and Finland (Wadud, 2012; Wei, 2003; Ah keng 2012). In Middle East (Fatoki, 2014) and Asia (Inda et al., 2015; Amal et al 2013) developing countries there have been ongoing research. Most of the researches are conducted in the field of customer satisfaction depending upon the findings among the countries such as China, Nigeria and Thailand (Lim, 2009; Fateemoh 2012; Ashim, 2011). On the contrary there have been limited researches conducted on European countries. The research conducted in past have revealed that customer retention and satisfaction are going to be a focus of online shopping and tourism, business sector and fast food industry, education and technology (Yeji, 2012; Susan, 2005; Sameul, 2004; Ong and Wai 2013).

Product quality (Wei Chia, 2003) variables have been most quoted in the previous studies, revealed in the recent research. (Ross, 2014) revealed that satisfaction of customers is the best indicator to analyze the trend of future sales. There is a competition between organizations in order to satisfy their customers by adopting ways to improve their quality and service. On the other hand, there are few organizations which lack skills to satisfy their customers. And when the customer is not satisfied from the service or product they are prone not to share or recommend others which affect the sales and might lead to financial crises for the company (Paul, 2011).

Analyzing customer satisfaction helps the organizations to adopt the skills and practices to improve their sales and to increase their strength of customers. Similarly, the fast food restaurants are constantly thriving to serve the best quality food with best services to increase the level of customer satisfaction. Therefore, this research focus would be to analyze the factors which lead to customer satisfaction which helps us to see the trend of fast food restaurants. During 1940s the inception of fast food industry took place in South California which impacted American's eating habits and also the eating habits of Asians including several other countries around the globe (Schlosser, 2001).

The fast food consumption in Pakistan drastically increased. Factors impacting customers food preferences are as follows; eating out attraction, socializing, urbanization, college and university students taste preference, 
Pakistani family's dual income expediency and other aspects (Saeed and Baig 2012).

Globalization has impacted the food sales, processing and manufacturing, its utilization and arrangements, and people have started consuming snacks in a new way due to the significant growth of pizza, burgers, snacks and fizzy drinks.

Urbanization is one of the issues, causing alterations in the augmented income, youth sovereignty and lifestyles, as it has been quoted that need for food has a correlation with lifestyle of urbanized areas (Pingali 2004). Westernized food consumption increased as the level of income increased in the developing countries (Dyck and Regmi, 2001).

\subsection{Customer satisfaction}

A company can determine customer satisfaction level by examining qualities of brand characteristics offered by the company (Afsheen and Khan 2012).

Johan; stated customer mind is unpredictable because it comprises of complex set of ideas and thoughts. Alexander and Thorsten (1997) revealed the strategic characteristics such as customer satisfaction, services and product to gain competitive edge. In relation to relationship building and marketing, Customer satisfaction is the helping aid to retain customers for long term because customers who are un-satisfied are very prone to switch (Wu and Lin, 2011). The feeling of accomplishing inner desires is known as satisfaction as defined by (Zairi, 2000). Customer's loyalty is directly affected by their satisfaction (Lassar and Mittal 1998). If customer demand and needs are fulfilled by the service or products provided by a company leads to customer's loyalty, and adding in company's customer equity. Balance sheet does not reveal the company's profitability however it can also be calculated by customer base and the life time value, that is delivered by the customers to an organization. Satisfaction of Consumer is the central philosophy of marketing strategy and plays a pivotal role in an organization's success as suggested by Oliver (1993) in his study. Customer satisfaction is core principle of CRM modern tool that is being utilized by the marketers to retain and attract consumers.

Atmosphere has a significant impact on complete satisfaction and pleasure as revealed by Lim, (2010). To affect the customer's behavior the physical environment have proven to be useful to form graphic in the mind of customers. In dinning places bodily environment also plays an important role for customer's satisfaction. The total ambiance comprising of tunes, service, responsiveness and quality leads to perfect dining experience, increasing customer's satisfaction. Pleasure is dependent and varied from one's mindset as expressed by Oliver (1981).

Satisfaction is regarded as an extensive principle while aspect of satisfaction is support good quality, (Bitner and Zeithem, 2003). Complete satisfaction is an outcome from the usage of specific sort of services or products (Oliver 1981).

Devotion and fulfillment have a positive relationship, the meta-analysis by Henard and Szymanski (2001) revealed 15 major and positive correlations between the 2 variables. On the other hand a new fantasized relationship was quoted by Teel and Bearden (1983) between devotion and fulfillment.

\subsection{Product Quality/ Food Quality}

Product quality holds equal importance as quality of service in the restaurants industry. Because the more your product is reliable in aspect of quality the more customers will be satisfied and opt for your product. CRM, customer relationship management comprises of product quality which depicts how much the consumer is dependent upon the reliability of your main product. The consumer becomes loyal and an ambassador of your brand when he/she is fully satisfied by the reliability and consistency of services of restaurant resulting into increase of restaurant equity.

The component product quality has been argued by Eskildsen and Kristensen (2007), Fecikova (2004). Product quality is the features of product matching with 8 aspects such as features, durability, aesthetics, reliability, serviceability, conformance, customer perception of performance and quality argued by Shaharudin et al. (2012). In general aspect quality has been explained in 4 categories exceeding or meeting customer requirements, value for money, conformity and excellence towards requirements (Bednar and Reeves, 1994). According to Garvin (1984) product centric approach is adopted in durability and features, performance centric, for focusing on aesthetics and perceived quality a user-based approach is adopted, and in the last an approach related to manufacturing is adopted for highlighting the conformance and reliability.

The customer is satisfied when product quality meets their expectations and assumes the item to be of high quality, and on the contrary if it does not meet their parameters of perceived quality, they would assume product to be of low quality.

It is argued by other researchers that quality of a product is when it meets the needs of customers and by giving them satisfaction. The aim of keeping higher quality parameters is to deliver more customer satisfaction and a desire to elevate the revenues. In the aspect of food, freshness is considered to be an important sensory element affecting the factors like taste, smell and sight Delwiche, 2004). 


\subsection{Service quality}

According to Aleksandar et al (2006), service is known as tangible because it cannot be touched or seen it can only be experienced. Maintaining service quality is the most important aspect which helps to mold the product according to the services and as per customer's needs.

In the current era customers can opt between majority of retailers offering similar kinds of products and services. While it is important, retailer has to distinguish themselves from the competitors and gain competitive edge over them. Such as in food industry improve the service quality of restaurants, give the customers best services with quality maintained to keep them satisfied, resulting in retention of the customers (Kumar et al, 2010).

Gupta and Jain (2004) stated that when perceived quality of service is less than the perceived quality of service the customers tend to be dissatisfied. Organization's performance is analyzed by the association between the satisfaction of customer and expected quality service therefore measuring customer satisfaction give result of service quality.

According to Ayse (2007), good quality comprises of 2 main components: wants are fulfilled by the merchandiser, 2 it is free from insufficiencies.

Quantifying and evaluating service quality is difficult to conduct, because it is subjective and it is their perception (Jones \& George, 1991). It is evaluated when the consumer compares their actual experience with his perception.

\subsection{Ambiance}

The spatial look of a restaurant is an important factor which needs to be focused by the restaurants. The way the furniture is furnished, the distance and their sizes all comes under the umbrella of spatial look. Past few years the eating behaviors of people have changed, they have started to prefer dine out at a restaurant rather staying at home. Therefore due to the change in patterns consumers opt to rely more on quality of restaurants (Raajpoot 2002, 107).

In comparison to the old times customers save large portion of their time and experience to dine at a better environment (Ryu et al, 2010). Restaurants are under the pressure to put all their efforts for the interior decoration and to create a relaxing environment for consumers. The overall idea behind the restaurants is to give a different experience to customers by providing quality of food and a relaxing environment. With the trend of eating out people are looking for quality of food as well as their top preference. Customers expect good quality of food, comfortable ambience and high standard service from the restaurants (Liu, Tsai, Chou \& Horng 2013). If customers do not return back for the dining experience that means they were not satisfied by the atmosphere, the staff was not able to create an experience for them which satisfy their psychological, emotional and cognitive needs (Lin, 2010). For retaining the customers, the restaurant owners feel the urge to create an amazing ambience and environment in comparison to their competitors. This will keep the customers satisfied and loyal to their preferred restaurant $\mathrm{Xu}, 2007)$.

Environment factors divided in three categories social cue, design cue and ambient cue according to (Baker, 1987). Ambient cue is the entire overlook and ambience the restaurant possess, décor and interior decoration is design cue and the people in the restaurant represent social cues.

Atmosphere may have significant impact on Customers satisfaction. Physical environment creates image in customer's mind which influences their behavior towards the restaurants. It also includes Furniture, scent, music, and lightening which plays a role for creating overall an outclass environment (Lim, 2010).

\subsection{Price}

Price is an important factor in selecting a product. It is a reward or value proposition to the organization in exchange of satisfaction. Consumer need and wants has to be compatible with price. Setting up a price of a product or service is not easy because every customer has their perception built according to the price of a product; they estimate value of the service or product according to the price which further distinguishes the satisfaction. It also helps the customer to decide either to purchase or not Khan, (2011). According to Mattila \& Neill (2003) from the customer's point of view, price serves as an indicator to estimate their experience with a particular service or good. Therefore considering these aspects customers purchase on the basis of the price estimation Khan (2011). Skindaras (2009) highlighted that they came across many assorted products with different ranges of price. $\mathrm{P}$ of price is known as the major variable of marketing mix which helps to base the strategies accordingly, (Armstrong \& Kotter, 2012). Han (2009) states pricing to be one of the major elements which goes through frequent improvement. In addition cost is associated with restaurant service as quoted by (Conway \& Andaleeb, 2006) which differ from the style. Also added that style and price are associated which helps customers link the price charged to them with the services provided

Nowadays the competition is neck to neck due to which customers evaluate the price being charged to them in comparison to the services and quality provided to them. This makes difficult for the restaurants to keep their 
customers retained and differentiate themselves from their competitors (Grewal et al. 1998). As mentioned before physical environment and program have a positive close relationship which works together to achieve customer satisfaction within the restaurant industry with the targeted audience. As per Wildt \& Chang (1998) the value is defined by the customer perception regarding the quality. The study associated with the price the only element the consumers associate are price and quality instead of other complex characteristics (Chui et al. 2006).

\subsection{Trend of Fast Food consumption}

This research is conducted to evaluate the pattern of fast food and the customer satisfaction encompassing various factors.

According to the IBIS World report on "Industry Market Research Report 2018", the Global Food Industry has grown over the period of five years despite the change in factors such as consumer tastes and a recovering global economy. With the increase in disposable income the spending increased by the consumers on luxuries such as dinning out. Inclined with this the fast food operator started to gain benefits by providing full-service restaurants. The trend of Five years revealed growth by $3.5 \%$ in the Global Fast Food industry by generating revenue of \$668bn in 2018 (IBISWORLD 2018).

The Fast Food Market Overview Research revealed that by 2022 the Trend of Fast Food Industry is estimated to bloom from $\$ 533,244 \mathrm{M}$ to $\$ 743,859 \mathrm{M}$ at a $4.8 \%$ CAGR (Compound Annual Growth Rate). On the other hand, the researcher's claimed that consuming fast food causes various medical issues, obesity and overweight. This is the major reason effecting and restricting the growth of fast food restaurants industry. In result of this the pattern of consuming fast food is shifting towards the fast casual food from the fast food. As per WHO in 2014, the overweight ratio of the world population was $39 \%$ and $13 \%$ of the population suffered from obesity (Sneha Nathwani, 2017).

The Global encompasses regions, and countries. Therefore, the Fast Food Industry and Market of Pakistan is highlighted, further discussed the past and growth of Fast Food in Pakistan and centered around Karachi for this research.

Pakistan Fast Food restaurant industry is the $2^{\text {nd }}$ largest market, accounting $27 \%$ of value-added production and $16 \%$ total employment in the manufacturing sector. Pakistan is $8^{\text {th }}$ largest market in businesses related to fast food market around the world.

There is a significance change in the Pakistan's Fast Food industry, inclined with change in traditional eating habits and lifestyles. As fast food is growing at a rapid pace worldwide similar

case is in Pakistan. The fast food restaurants are increasing in Pakistan because consumers opt for eating conveniently, with economical prices and easy access. The branded international food chains like McDonalds, KFC, Pizza Hut etc, have contributed in the growth of Fast Food Market. The restaurants in Pakistan provides home delivery and take away option to its customers (Mohammad Arifeen December 2017).

For every one of us Food is the basic necessity and all of us earn money to fulfill our basic need. Pakistani people love eating and happily opt to try any new eatery opened in the town, which is one of the major reasons why the entire international brands happily open their franchises in Pakistan. Some of the International franchises have already opened their doors and are successfully running in Pakistan such as KFC, McDonalds and Hardees (Prof. Dr. Noor Ahmed Memon, 2016). The average calculation of the fast food business and the pattern of eating habits of people in Pakistan highlighted $21 \%$ increase annually, which reflects that the fast food business in Pakistan is exceeding 20\% annually causing it to be one of the fast growing businesses around globe.

KFC and McDonalds have presence in mostly the bigger cities of Pakistan with an expanding network. There are few new International entrants in the market of Pakistan such as Fat Burger, Burger King, and Hardees.

For this research selected Fast Food Outlets will be studied.

KFC is the first and the oldest fast food chain in Pakistan, opened in 1997. Its symbol is of taste and quality. Its first outlet in Pakistan was in Karachi.

McDonalds opened its doors in 1998 in Pakistan. It has presence in Karachi, Lahore, Islamabad, Hyderabad, Faisalabad, and Rawalpindi. It has a strong belief in "when it is green it is growing".

Burger King is one of the popular and leading fast food around the world. However it is new in Pakistan in comparison to other outlets. Their existence is in Karachi, Islamabad, Lahore and Multan. Came to Pakistan mid of 2014.

Hardee's $4^{\text {th }}$ biggest fast food outlet in the world and is also popular in Pakistan holding tantalizing taste and good menu. Existence is in Multan, Faisalabad, Islamabad, Lahore and Karachi. Pakistan was on $14^{\text {th }}$ number as a host of the brand. Its first branch opened in Lahore at M.M Alam road.

Singh and Goyal (2007) proposed that consumers encompassing youth visit fast food restaurants for change and entertainment. Fast food restaurants have been innovation and found a way to bring people out of their kitchens. Structured changes in the outlook of fast food in Asia have exposed that people of Asia, Asian countries, have been facing transformations in their economies backed by frequent urbanization and the trend tends to continue Howarth and Huang, 1996). Food is a means of life but now it has become means for business 
investment as per Food in a globalized World (Ragavan, 2003).

The study is conducted to explore the factors that influence the customer's satisfaction and analyzing the trend by observing the pattern which restaurant is opted more and why. There are core strategies to attract the customers towards restaurants, which have been described and adopted by various companies of fast food in Pakistan. Fast food restaurants identify the gap to be filled and understand the needs of customers, according to which they base their strategies, for instance restaurants offering early breakfast. For example, McDonald's during Ramadan started offering Sehri deals.

\subsection{Problem Statement}

Customer satisfaction is the key to any business success therefore all the organizations thrive to satisfy their customers to retain them and increase profits Paul, 2011). Customer satisfaction in fast food industry is pivotal due to the increased competition.

\subsection{Definitions}

Fast food: Dictionary by Oxford defines fast food as 'food that can be easily and quickly prepared that is sold in snack bars and restaurants as a quick meal or to be taken out'.

Customer Satisfaction: Meeting customers' expectations associated with the parameters of satisfaction (Ghaffor, \& Malik 2012).

\subsection{Purpose of Research}

The aim to deduce in this research is to find the factors leading to customer satisfaction highlighting the fast food trend.

\subsection{Focus of the Research}

The research focus is on Sindh, Karachi Urban Region. However it is vital to note that the research is based on Customers of Fast Food restaurants situated in Clifton, Defence surrounding areas.

\subsection{Research Objective}

1. The core objective of this research is to gauge and evaluate the factors of customer satisfaction highlighting the fast food trend.

2. Furthermore, the sub objectives of this research will also allow the reader to know which factor leads to customer's satisfaction.

3. In addition, the research sought to discover how satisfied customers decide the trend of fast food restaurant, that what factors make customer's satisfied and why they prefer a specific fast food outlet.

\subsection{Hypotheses}

$\mathrm{H}_{1}$ : Quality of Service has an association with Customer Satisfaction

$\mathrm{H}_{2:}$ Ambience has an association with Customer Satisfaction

$\mathrm{H}_{3}$ : Price impacts has an association with Customer Satisfaction

$\mathrm{H}_{4}$ : Quality of Food has an association with Customer Satisfaction

$\mathrm{H}_{5}$ : Factors of customer satisfaction leads to Analyzing Fast Food Trend

\subsection{Conceptual Framework}

This paper proposes the conceptual framework given below on the basis of existing literature review, finding, comparing and critically analyzing the fundamental factors of customer and satisfaction and the impact of fast food, which restaurant is being preferred more on the basis of those factors.

The below given conceptual framework (Figure. 1) proposes 4 variables, Service, Ambience (Physical Environment, Pricing, Quality of Food, and Quality of Food (Product Quality). Further it incorporates demographics and location, analyzing the trend of fast food restaurants.

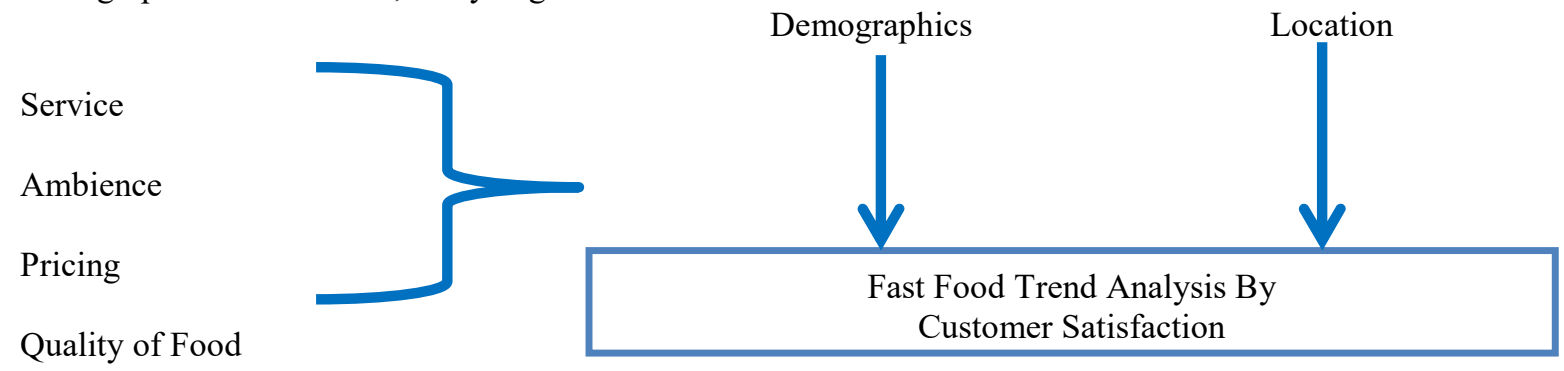

Figure: 1 


\subsection{Methodology}

\subsection{Research Method}

This dissertation is a mix of quantitative and qualitative variables; the data gathered was further quantified in this research. This method reduced the bias level as the analysis is based on the results of the software.

\subsection{Research Dimension}

The research dimension is indeed causal. Causal study tends to focus on the cause and effect relationship between variables. It investigates how a particular variable or variables tend to have an effect or cause on another. Similarly in this current research the impact of Service, Price, Ambiance, and Quality has on Customer Satisfaction is studied further analyzing the Fast Food Trend.

\subsection{Time Orientation}

The time orientation is cross sectional due to the time constraint.

\subsection{Sample size and Information Source}

This research utilizes 122 customers of various fast food outlets such as Burger King, Hardees, Mc Donald's, and KFC. Information gathered from the customers of the fast food restaurant there and then.

\subsection{Sampling Techniques and Procedure}

The technique used to acquire my sample for this research was via Convenience Sampling technique. This is to maintain the quality of research so only concerned people filled out the questionnaires, 100 individuals were selected for this study.

\subsection{Data Collection Methods}

\subsection{Primary Data and Data Collection Tool}

Questionnaire survey is used as a tool for primary research and collection of data. The Questionnaires are structured on a likert scale from 1 to 5 . In the questionnaire"1" represented the highest level of disagreement whereas " 5 " represented the highest level of agreement.

\subsection{Result Analysis and Discussion}

Results analysis is conducted in two ways, one is descriptive and the other is inferential. Both are incorporated in this study. The descriptive analysis is mentioned in the corresponding paragraphs and the tables of the results generated are given below in appendix section. The analysis conducted based on gender table: 1 revealed out of 122 population male respondents are 65 and female respondents are 57 . The percentages of male are 53.3 and female 46.7 which gave feedback. Table 1.1 revealed the age criteria set was from 15 years of age to 45 years. Amongst which 15-25 respondent's percentage is 49.2, 26-35 percentage is 46.7 and 36-45 respondents' percentage is $4.1 \%$. the respondent's percentage to the response of visiting the restaurants frequently was $100 \%$. Table 1.3 showcased that KFC and McDonalds are the most preferred outlets in which McDonald's percentage turned out to be the highest amongst others i.e. 50 then the second most preferred outlet is KFC with $33.6 \%$, Burger King 9.0 and the least preferred is Hardees at 7.4\%. As per previous research conducted on fast food restaurant in Malaysia revealed, service quality have a significant relationship with customer satisfaction Ali Dehgan (2006), similarly this research table 7.0 and 7.1 demonstrates the relationship between service quality and customer relationship which revealed the relationship between the variables is weak, if it was $50 \%$ then it was moderate relationship therefore $.381 \%$ and .351 reveals that relationship is weak but there is a significant relationship so that means hypotheses 1 is accepted. Table of ambiance and customer satisfaction 8.0 and 8.1 demonstrated a good relationship between ambiance and customer satisfaction and the relationship is also significant which implies hypotheses 2 is accepted. Hypotheses 3 Price has an association with Customer Satisfaction has been accepted as revealed by table 9.0 and 9.1 there is a moderate relationship between two variables but the hypotheses 3 is accepted because of the significance. The relationship between quality of food and customer satisfaction is moderate as per the table 10.0 and 10.1 which means that if it was above $60 \%$ the relationship would have been strong. However due to the significance the hypotheses 4 is accepted.

Table 11.2 revealed the regression is significant .000, Ambiance, Pricing and Quality of Food have influence on Customer satisfaction due to their significance.

\subsection{Discussion}

For this research study Service Quality, Pricing, Ambiance and Quality of Food were taken as independent variables and customer satisfaction was kept as a dependent variable in which due to the results generated it revealed that Pricing, Ambiance and Quality of Food have positive influence on customer satisfaction. 


\subsection{Conclusion}

The research aimed to highlight the variables which have influence on the customer satisfaction. And the variables ambiance, price and quality of food have positive influence on customer satisfaction which means that particular food outlet is preferred over the other due to the three factors mentioned above. The trend is also highlighted that which fast food restaurant is preferred more over the other and why. The results revealed that McDonalds and KFC are the most preferred fast food outlets which mean that trend is towards these two multinational fast food chains.

\section{References}

Dastane, O., \& Fazlin, I. (2017). Re-Investigating Key Factors of Customer Satisfaction Affecting Customer Retention for Fast Food Industry.Kau, A. K., \& Wan-Yiun Loh, E. (2006). The effects of service recovery on consumer satisfaction: a comparison between complainants and non-complainants. Journal of Services Marketing, 20(2), 101-111.

Wadud Sharmin, (2012). Customer satisfaction in business: A case study of Moon Travel LTD, Finland [pdf] Available at: https:/www.theseus.fi/bitstream/handle/10024/ 54685/Wadud\%20Sharmin.pdf?sequence=1[Accessed 20 November 2015].

Fatoki, O. (2014). The entrepreneurial intention of undergraduate students in South Africa: The influences of entrepreneurship education and previous work experience. Mediterranean Journal of Social Sciences, 5(7), 294.

Goyal, A. and Singh, N.P. (2007), "Consumer perception about fast food in India: an exploratory Study", British Food Journal, Vol. 109 No. 2, pp. 182-95

Seo, Y. (2012). Cultural impact on customer satisfaction and service quality evaluation in hotels.

Otim, S. (2004). The Determinants and implications of customer satisfaction and loyalty in web-based commerce: An Empirical analysis.

Tung, W. C. (2003). A CUSTOMER PERCEPTION AND SATISFACTION SURVEY FOR A (Doctoral dissertation, University of Wisconsin-Stout).and service quality (Ali 2006; Oladejo 2010; Wadud 2012)

Ali Dehghan. (2006). Relationship between Service quality and customer satisfaction [pdf] Available at: http://epubl.ltu.se/1653-0187/2006/56/LTU-PB-EX-0656-SE.pdf [Accessed 2 September 2015].

Beard, R. (2014). Why customer satisfaction is important (6 Reasons). Client Heartbeat.

Paul Linnell, (2015). Cost of poor service - the economic truths [online] Available at: http://ctmaworld.com/economictruths.htm [Accessed 2 November 2015].

Hassim, N. (2016). Factors Affecting Customer Satisfaction In Fast Food Restaurants.

Sabir, R. I., Irfan, M., Sarwar, M. A., Sarwar, B., \& Akhtar, N. (2014). Journal of Asian Business Strategy. Journal of Asian Business Strategy, 4(5), 58-73.

Regmi, A., \& Dyck, J. (2001). Effects of urbanization on global food demand. Changing structure of global food consumption and trade, 23-30.

Baig, A. K., \& Saeed, M. (2012). Review of trends in fast food consumption. European Journal of Economics, Finance and Administrative Sciences, 48, 77-85.

Pingali, P. (2007). Westernization of Asian diets and the transformation of food systems: Implications for research and policy. Food policy, 32(3), 281-298.

Hennig-Thurau, T., \& Klee, A. (1997). The impact of customer satisfaction and relationship quality on customer retention: A critical reassessment and model development. Psychology \& marketing, 14(8), 737-764.

Shahzad Khan, S. A. (2012). Determinants of customer satisfaction in telecom industry; a study of telecom industry Peshawar KPK Pakistan. Journal of Basic and Applied Scientific Research, vol, 2(12), 1283312840 .

Lin, J. S. C., \& Wu, C. Y. (2011). The role of expected future use in relationship-based service retention. Managing Service Quality: An International Journal, 21(5), 535-551.

Zairi, M. (2000). Managing customer dissatisfaction through effective complaints management systems. The TQM magazine, 12(5), 331-337.

Mittal, B., \& Lassar, W. M. (1998). Why do customers switch? The dynamics of satisfaction versus loyalty. Journal of services marketing, 12(3), 177-194.

Oliver, R. L. (1993). A Conceptual Model of Service Quality and Service Satisfaction: Comparative Goals, Different Concepts. Advances in service marketing and management, 2, 65-85.

Oliver, R. L. (1981). Measurement and evaluation of satisfaction processes in retail settings. Journal of retailing.

Bearden, W. O., \& Teel, J. E. (1983). Selected determinants of consumer satisfaction and complaint reports. Journal of marketing Research, 21-28.

Szymanski, D. M., \& Henard, D. H. (2001). Customer satisfaction: A meta-analysis of the empirical evidence. Journal of the academy of marketing science, 29(1), 16-35.

Jakpar, S., Goh, S., Johari, A., \& Myint, K. (2012). Examining the product quality attributes that influences 
customer satisfaction most when the price was discounted: a case study in Kuching Sarawak. International Journal of Business and Social Science, 3(23), 221-236.

Fečiková, I. (2004). An index method for measurement of customer satisfaction. The TQM magazine, 16(1), 5766.

Garvin, D. A., \& Quality, W. D. P. (1984). Really Mean. Sloan management review, 25.

Reeves, C. A., \& Bednar, D. A. (1994). Defining quality: alternatives and implications. Academy of management Review, 19(3), 419-445.

Kumar, S. A., Mani, B., Mahalingam, S., \& Vanjikovan, M. (2010). Influence of Service Quality on Attitudinal Loyalty in Private Retail Banking: An Empirical Study. IUP Journal of Management Research, 9(4).

Ryu, K., \& Han, H. (2010). Influence of the quality of food, service, and physical environment on customer satisfaction and behavioral intention in quick-casual restaurants: Moderating role of perceived price. Journal of Hospitality \& Tourism Research, 34(3), 310-329.

Raajpoot, N. A. (2002). TANGSERV: A multiple item scale for measuring tangible quality in foodservice industry. Journal of Foodservice Business Research, 5(2), 109-127.

Horng, J. S., Chou, S. F., Liu, C. H., \& Tsai, C. Y. (2013). Creativity, aesthetics and eco-friendliness: A physical dining environment design synthetic assessment model of innovative restaurants. Tourism Management, 36, $15-25$.

$\mathrm{Xu}, \mathrm{Y}$. (2007). Impact of store environment on adult generation Y consumers' impulse buying. Journal of Shopping Center Research, 14(1), 39-56.

Karki, D., \& Panthi, A. (2018). A study on Nepalese Restaurants in Finland: How Food Quality, Price, Ambiance and Service Quality Effects Customer Satisfaction.

Lim, H. (2010). Understanding American customer perceptions on Japanese food and services in the US.

Khan, N. A. (2011). A study of brands in the food and beverages industry of pakistan. International journal of business and social science, 2(13), 262-271.

Mattila, A. S., \& O'Neill, J. W. (2003). Relationships between hotel room pricing, occupancy, and guest satisfaction: A longitudinal case of a midscale hotel in the United States. Journal of Hospitality \& Tourism Research, 27(3), 328-341.

Virvalaite, R., Saladiene, V., \& Skindaras, D. (2009). The relationship between price and loyalty in services industry. Engineering Economics, 63(4).

Lim, H. (2010). Understanding American customer perceptions on Japanese food and services in the US

Saad Andaleeb, S., \& Conway, C. (2006). Customer satisfaction in the restaurant industry: an examination of the transaction-specific model. Journal of services marketing, 20(1), 3-11.

Chang, T. Z., \& Wildt, A. R. (1996). Impact of product information on the use of price as a quality cue. Psychology \& Marketing, 13(1), 55-75.

Chiu, Y. J., Chen, H. C., Tzeng, G. H., \& Shyu, J. Z. (2006). Marketing strategy based on customer behaviour for the LCD-TV. International journal of management and decision making, 7(2-3), 143-165.

Grewal, D., Monroe, K. B., \& Krishnan, R. (1998). The effects of price-comparison advertising on buyers' perceptions of acquisition value, transaction value, and behavioral intentions. The Journal of Marketing, 4659.

Huang, J. and Howarth, B. (1996), "Structural changes in the demand for food in Asia", December 1996, 2020 Vision Brief 41.

Ragavan, P. (2003), "Food in a globalised world - a cultural perspective", Journal of International University Centre, I.I.A.S. Shimla, Vol. 10 No. 1, pp. 143-56. 


\section{Tables Appendix}

\begin{tabular}{|ll|r|r|r|r|}
\hline & \multicolumn{1}{|c|}{ Gender } \\
\hline \multirow{3}{*}{ Valid } & \multicolumn{1}{|c|}{ Frequency } & \multicolumn{1}{|c|}{ Percent } & \multicolumn{1}{l|}{ Valid Percent } & Cumulative Percent \\
& Male & 65 & 53.3 & 53.3 & 53.3 \\
& Female & 57 & 46.7 & 46.7 & 100.0 \\
& Total & 122 & 100.0 & 100.0 & \\
\hline
\end{tabular}

Table: 1.0

\begin{tabular}{|c|c|c|c|c|c|}
\hline \multicolumn{6}{|c|}{ Age } \\
\hline & & Frequency & Percent & Valid Percent & Cumulative Percent \\
\hline \multirow{4}{*}{ Valid } & $15-25$ & 60 & 49.2 & 49.2 & 49.2 \\
\hline & $26-35$ & 57 & 46.7 & 46.7 & 95.9 \\
\hline & $36-45$ & 5 & 4.1 & 4.1 & 100.0 \\
\hline & Total & 122 & 100.0 & 100.0 & \\
\hline
\end{tabular}

Table: 1.1

Do you visit fast food restaurants?

\begin{tabular}{|ll|r|r|r|r|}
\hline & \multicolumn{2}{|c|}{ Frequency } & Percent & Valid Percent & Cumulative Percent \\
\hline Valid & Yes & 122 & 100.0 & 100.0 & 100.0 \\
\hline
\end{tabular}

\section{Table: 1.2}

Frequency for the particular factor is 122 in which the percentage result turned out 100.

Which Fast food restaurant do you visit most?

\begin{tabular}{|ll|r|r|r|r|}
\hline & \multicolumn{1}{|c|}{ Frequency } & Percent & Valid Percent & Cumulative Percent \\
\hline \multirow{4}{*}{ Valid } & 9 & 7.4 & 7.4 & 7.4 \\
& Hardees & 11 & 9.0 & 9.0 & 16.4 \\
& Burger King & 41 & 33.6 & 33.6 & 50.0 \\
& KFC & 61 & 50.0 & 50.0 & 100.0 \\
& McDonalds & 122 & 100.0 & 100.0 & \\
\hline
\end{tabular}

\section{Table: 1.3}

Their staff is friendly and cooperative which makes you visit them often?

\begin{tabular}{|rl|r|r|r|r|}
\hline & \multicolumn{1}{|c|}{ Frequency } & Percent & Valid Percent & Cumulative Percent \\
\hline \multirow{4}{*}{ Valid } & 4 & 3.3 & 3.3 & 3.3 \\
& SD & 13 & 10.7 & 10.7 & 13.9 \\
& D & 37 & 30.3 & 30.3 & 44.3 \\
& $\mathrm{~N}$ & 61 & 50.0 & 50.0 & 94.3 \\
& $\mathrm{~A}$ & 7 & 5.7 & 5.7 & 100.0 \\
& SA & 122 & 100.0 & 100.0 & \\
\hline
\end{tabular}

Table: 2.0

Out of 122 respondents the highest percentage is of Agree i.e. 50.0 which makes it up half percentage from 100 .

The food is served within mentioned time duration

\begin{tabular}{|rl|r|r|r|r|}
\hline & Frequency & Percent & Valid Percent & Cumulative Percent \\
\hline & SD & 1 & .8 & .8 & .8 \\
& D & 9 & 7.4 & 7.4 & 8.2 \\
Valid & 28 & 23.0 & 23.0 & 31.1 \\
& $\mathrm{~N}$ & 69 & 56.6 & 56.6 & 87.7 \\
& $\mathrm{~A}$ & 15 & 12.3 & 12.3 & 100.0 \\
& SA & 122 & 100.0 & 100.0 & \\
& Total & & & \\
\hline
\end{tabular}

Table:2.1

The highest percentage of the respondents is 56.6 which is the agreement for the time duration. 
Does your preferred fast food restaurant give individual attention, which drives you to visit them?

\begin{tabular}{|rl|r|r|r|r|}
\hline & Frequency & Percent & Valid Percent & Cumulative Percent \\
\hline & SD & 1 & .8 & .8 & .8 \\
& D & 20 & 16.4 & 16.4 & 17.2 \\
Valid & N & 34 & 27.9 & 27.9 & 45.1 \\
& A & 59 & 48.4 & 48.4 & 93.4 \\
& SA & 8 & 6.6 & 6.6 & 100.0 \\
& Total & 122 & 100.0 & 100.0 & \\
\hline
\end{tabular}

\section{Table:2.2}

The highest percentage is 48.4 which is of agreement.

They provide quick and convenient services to you, that is why you choose to visit them?

\begin{tabular}{|c|c|c|c|c|c|}
\hline & & Frequency & Percent & Valid Percent & Cumulative Percent \\
\hline \multirow{6}{*}{ Valid } & SD & 3 & 2.5 & 2.5 & 2.5 \\
\hline & $\mathrm{D}$ & 12 & 9.8 & 9.8 & 12.3 \\
\hline & $\mathrm{N}$ & 26 & 21.3 & 21.3 & 33.6 \\
\hline & A & 63 & 51.6 & 51.6 & 85.2 \\
\hline & SA & 18 & 14.8 & 14.8 & 100.0 \\
\hline & Total & 122 & 100.0 & 100.0 & \\
\hline
\end{tabular}

Table: 2.3

Out of 122 respondents agreeing to the particular statement percentage is highest 51.6

Do you like the decorations and interior of the preferred restaurant?

\begin{tabular}{|rl|r|r|r|r|}
\hline & Frequency & Percent & Valid Percent & Cumulative Percent \\
\hline \multirow{4}{*}{ Valid } & SD & 2 & 1.6 & 1.6 & 1.6 \\
& D & 16 & 13.1 & 13.1 & 14.8 \\
& N & 38 & 31.1 & 31.1 & 45.9 \\
& A & 48 & 39.3 & 39.3 & 85.2 \\
& SA & 18 & 14.8 & 14.8 & 100.0 \\
& Total & 122 & 100.0 & \\
\hline
\end{tabular}

Table:3.0

48 respondents out of 122 agreed to the above statement which is 39.3 percent of the total

They have comfortable seating arrangement which adds on to quality of service?

\begin{tabular}{|c|c|c|c|c|c|}
\hline & & Frequency & Percent & Valid Percent & Cumulative Percent \\
\hline \multirow{6}{*}{ Valid } & SD & 1 & .8 & .8 & .8 \\
\hline & $\mathrm{A}$ & 15 & 12.3 & 12.3 & 13.1 \\
\hline & $\mathrm{N}$ & 30 & 24.6 & 24.6 & 37.7 \\
\hline & $\mathrm{A}$ & 62 & 50.8 & 50.8 & 88.5 \\
\hline & SA & 14 & 11.5 & 11.5 & 100.0 \\
\hline & Total & 122 & 100.0 & 100.0 & \\
\hline
\end{tabular}

Table:3.1

62 people agreed to the statement which is 50.8 percent of the total 
They play good and soothing music which gives an amusing feeling

\begin{tabular}{|c|c|c|c|c|c|}
\hline & & Frequency & Percent & Valid Percent & Cumulative Percent \\
\hline \multirow{6}{*}{ Valid } & SD & 6 & 4.9 & 4.9 & 4.9 \\
\hline & $\mathrm{D}$ & 35 & 28.7 & 28.7 & 33.6 \\
\hline & $\mathrm{N}$ & 36 & 29.5 & 29.5 & 63.1 \\
\hline & $\mathrm{A}$ & 37 & 30.3 & 30.3 & 93.4 \\
\hline & SA & 8 & 6.6 & 6.6 & 100.0 \\
\hline & Total & 122 & 100.0 & 100.0 & \\
\hline
\end{tabular}

\section{Table:3.2}

37 people agreed to it while 36 respondents were neutral.

They have a clean place, furniture and tables which helps you to enjoy your food more?

\begin{tabular}{|c|c|c|c|c|c|}
\hline & & Frequency & Percent & Valid Percent & Cumulative Percent \\
\hline \multirow{6}{*}{ Valid } & SD & 2 & 1.6 & 1.6 & 1.6 \\
\hline & $\mathrm{D}$ & 8 & 6.6 & 6.6 & 8.2 \\
\hline & $\mathrm{N}$ & 30 & 24.6 & 24.6 & 32.8 \\
\hline & A & 60 & 49.2 & 49.2 & 82.0 \\
\hline & SA & 22 & 18.0 & 18.0 & 100.0 \\
\hline & Total & 122 & 100.0 & 100.0 & \\
\hline
\end{tabular}

\section{Table:3.3}

The highest percent is 49.2 which means 60 respondents have agreed with this statement

The restaurant's overall prices of the food are affordable in comparison to others

\begin{tabular}{|rl|r|r|r|r|}
\hline & Frequency & Percent & Valid Percent & Cumulative Percent \\
\hline \multirow{4}{*}{ Valid } & 4 & 3.3 & 3.3 & 3.3 \\
& SD & 18 & 14.8 & 14.8 & 18.0 \\
& D & 37 & 30.3 & 30.3 & 48.4 \\
& $\mathrm{~N}$ & 55 & 45.1 & 45.1 & 93.4 \\
& $\mathrm{~A}$ & 8 & 6.6 & 6.6 & 100.0 \\
& SA & 122 & 100.0 & 100.0 & \\
& Total & &
\end{tabular}

Table:4.0

55 respondents, $45.1 \%$ have agreed their preferred restaurant charges reasonable pricess in comparison to others.

They charge fair price for the quality of food they provide?

\begin{tabular}{|c|c|c|c|c|c|}
\hline & & Frequency & Percent & Valid Percent & Cumulative Percent \\
\hline \multirow{6}{*}{ Valid } & SD & 4 & 3.3 & 3.3 & 3.3 \\
\hline & $\mathrm{D}$ & 10 & 8.2 & 8.2 & 11.5 \\
\hline & $\mathrm{N}$ & 38 & 31.1 & 31.1 & 42.6 \\
\hline & $\mathrm{A}$ & 59 & 48.4 & 48.4 & 91.0 \\
\hline & SA & 11 & 9.0 & 9.0 & 100.0 \\
\hline & Total & 122 & 100.0 & 100.0 & \\
\hline
\end{tabular}

\section{Table:4.1}

59 respondents are satisfied with the price charged to them by their preferred restaurant out of 122 respondents which makes it $48.4 \%$. 
The price charged for the food along with the value added services is reasonable in comparison to others?

\begin{tabular}{|rl|r|r|r|r|}
\hline & \multicolumn{1}{|c|}{ Frequency } & Percent & Valid Percent & Cumulative Percent \\
\hline & SD & 3 & 2.5 & 2.5 & 2.5 \\
& Valid & 16 & 13.1 & 13.1 & 15.6 \\
& N & 37 & 30.3 & 30.3 & 45.9 \\
& A & 56 & 45.9 & 45.9 & 91.8 \\
& SA & 10 & 8.2 & 10.2 & 100.0 \\
& Total & 122 & 100.0 & 100.0 & \\
\hline
\end{tabular}

Table: 4.2

56 respondents have agreed to the above mentioned statement which makes it the highest percent $45.9 \%$

The fast food restaurant overall provides fair and reasonable deals for the customers?

\begin{tabular}{|c|c|c|c|c|c|}
\hline & & Frequency & Percent & Valid Percent & Cumulative Percent \\
\hline \multirow{6}{*}{ Valid } & SD & 3 & 2.5 & 2.5 & 2.5 \\
\hline & $\mathrm{D}$ & 8 & 6.6 & 6.6 & 9.0 \\
\hline & $\mathrm{N}$ & 34 & 27.9 & 27.9 & 36.9 \\
\hline & A & 62 & 50.8 & 50.8 & 87.7 \\
\hline & SA & 15 & 12.3 & 12.3 & 100.0 \\
\hline & Total & 122 & 100.0 & 100.0 & \\
\hline
\end{tabular}

Table:4.3

62 respondents have responded positively to the above statement which means they all agreed with it which is the $50.8 \%$ of total 122 .

The presentation of food is appealing?

\begin{tabular}{|rl|r|r|r|r|}
\hline & Frequency & Percent & Valid Percent & Cumulative Percent \\
\hline \multirow{4}{*}{ Valid } & S & 3 & 2.5 & 2.5 & 2.5 \\
& $\mathrm{~N}$ & 35 & 28.7 & 28.7 & 31.1 \\
& $\mathrm{~A}$ & 67 & 54.9 & 54.9 & 86.1 \\
& SA & 17 & 13.9 & 13.9 & 100.0 \\
& Total & 122 & 100.0 & 100.0 & \\
\hline
\end{tabular}

Table:5.0

67 respondents are appealed by the presentation of food due to which 67 out of 122 have agreed making it $54.9 \%$

The freshness of food impacts your decision to buy from them?

\begin{tabular}{|rl|r|r|r|r|}
\hline & Frequency & Percent & Valid Percent & Cumulative Percent \\
\hline \multirow{4}{*}{ Valid } & SD & 2 & 1.6 & 1.6 & 1.6 \\
& D & 2 & 1.6 & 1.6 & 3.3 \\
& N & 24 & 19.7 & 19.7 & 23.0 \\
& A & 70 & 57.4 & 57.4 & 80.3 \\
& SA & 24 & 19.7 & 19.7 & 100.0 \\
& Total & 122 & 100.0 & 100.0 & \\
\hline
\end{tabular}

Table:5.1

For 70 people out of 122 freshness of the food matters due to which $57.4 \%$ have agreed 
The food served is hygienic and fresh?

\begin{tabular}{|c|c|c|c|c|c|}
\hline & & Frequency & Percent & Valid Percent & Cumulative Percent \\
\hline \multirow{6}{*}{ Valid } & SD & 2 & 1.6 & 1.6 & 1.6 \\
\hline & D & 3 & 2.5 & 2.5 & 4.1 \\
\hline & $\mathrm{N}$ & 31 & 25.4 & 25.4 & 29.5 \\
\hline & A & 69 & 56.6 & 56.6 & 86.1 \\
\hline & SA & 17 & 13.9 & 13.9 & 100.0 \\
\hline & Total & 122 & 100.0 & 100.0 & \\
\hline
\end{tabular}

Table:5.2

69 respondents believe food served by their preferred outlet is hygienic

Do they meet your expectations of quality perceived by you?

\begin{tabular}{|c|c|c|c|c|c|}
\hline & & Frequency & Percent & Valid Percent & Cumulative Percent \\
\hline \multirow{6}{*}{ Valid } & SD & 1 & .8 & .8 & .8 \\
\hline & $\mathrm{D}$ & 3 & 2.5 & 2.5 & 3.3 \\
\hline & $\mathrm{N}$ & 34 & 27.9 & 27.9 & 31.1 \\
\hline & $\mathrm{A}$ & 71 & 58.2 & 58.2 & 89.3 \\
\hline & SA & 13 & 10.7 & 10.7 & 100.0 \\
\hline & Total & 122 & 100.0 & 100.0 & \\
\hline
\end{tabular}

\section{Table:5.3}

$58.2 \%$ agreed to the above mentioned statement

You are satisfied by them because of the quality of food they provide?

\begin{tabular}{|rl|r|r|r|r|}
\hline & Frequency & Percent & Valid Percent & Cumulative Percent \\
\hline & SD & 1 & .8 & .8 & .8 \\
& D & 8 & 6.6 & 6.6 & 7.4 \\
Valid & 24 & 19.7 & 19.7 & 27.0 \\
& N & 73 & 59.8 & 59.8 & 86.9 \\
& A & 16 & 13.1 & 13.1 & 100.0 \\
& SA & 122 & 100.0 & 100.0 & \\
& Total & 16 & \\
\end{tabular}

73 respondents are satisfied with the quality of food is provided to them which makes it $59.8 \%$

Your preferred outlet prices are affordable which leads you to buy their food often?

\begin{tabular}{|c|c|c|c|c|c|}
\hline & & Frequency & Percent & Valid Percent & Cumulative Percent \\
\hline \multirow{6}{*}{ Valid } & SD & 2 & 1.6 & 1.6 & 1.6 \\
\hline & $\mathrm{D}$ & 17 & 13.9 & 13.9 & 15.6 \\
\hline & $\mathrm{N}$ & 36 & 29.5 & 29.5 & 45.1 \\
\hline & A & 57 & 46.7 & 46.7 & 91.8 \\
\hline & SA & 10 & 8.2 & 8.2 & 100.0 \\
\hline & Total & 122 & 100.0 & 100.0 & \\
\hline
\end{tabular}

Table: 6.0

57 respondents are satisfied by the prices charged to them which makes $46.7 \%$ out of $100 \%$ 
The ambience of your preferred outlet is pleasant which satisfies you?

\begin{tabular}{|c|c|c|c|c|c|}
\hline & & Frequency & Percent & Valid Percent & Cumulative Percent \\
\hline \multirow{6}{*}{ Valid } & SD & 1 & .8 & .8 & .8 \\
\hline & $\mathrm{D}$ & 8 & 6.6 & 6.6 & 7.4 \\
\hline & $\mathrm{N}$ & 36 & 29.5 & 29.5 & 36.9 \\
\hline & $\mathrm{A}$ & 67 & 54.9 & 54.9 & 91.8 \\
\hline & SA & 10 & 8.2 & 8.2 & 100.0 \\
\hline & Total & 122 & 100.0 & 100.0 & \\
\hline
\end{tabular}

\section{Table:6.1}

67 respondents like the ambience of the preferred outlet which makes them visit more often.

The services they provide are better than other fast food outlets which make you happy and want to visit them often?

\begin{tabular}{|rl|r|r|r|r|}
\hline & Frequency & Percent & Valid Percent & Cumulative Percent \\
\hline & SD & 1 & .8 & .8 & .8 \\
& D & 8 & 6.6 & 6.6 & 7.4 \\
Valid & 37 & 30.3 & 30.3 & 37.7 \\
& N & 59 & 48.4 & 48.4 & 86.1 \\
& A & 17 & 13.9 & 13.9 & 100.0 \\
& SA & 122 & 100.0 & 100.0 & \\
& Total & & & \\
\hline
\end{tabular}

\section{Table: 6.2}

59 respondents are happy out of 122 with the services

You opt to visit your desired fast food restaurant because of the location?

\begin{tabular}{|rl|r|r|r|r|}
\hline & Frequency & Percent & Valid Percent & Cumulative Percent \\
\hline & SD & 2 & 1.6 & 1.6 & 1.6 \\
& D & 8 & 6.6 & 6.6 & 8.2 \\
& Valid & 22 & 18.0 & 18.0 & 26.2 \\
& A & 60 & 49.2 & 49.2 & 75.4 \\
& SA & 30 & 24.6 & 24.6 & 100.0 \\
& Total & 122 & 100.0 & 100.0 & \\
\hline
\end{tabular}

\section{Table: 6.3}

60 respondents out of 122 responded they visit the fast food outlet due to the location which means $49.2 \%$

\section{Inferential Statistics}

Relationship between Service Quality and Customer Satisfaction

\section{Correlations}

\begin{tabular}{|ll|r|r|}
\hline & & Independent1 & Dependent \\
\hline \multirow{3}{*}{ Independent1 } & Pearson Correlation & 1 & $.381^{* *}$ \\
& Sig. (2-tailed) & .000 \\
& $\mathrm{~N}$ & 122 & 122 \\
Dependent & Pearson Correlation & $.381^{* *}$ & 1 \\
& Sig. (2-tailed) & .000 & 122 \\
\hline
\end{tabular}

**. Correlation is significant at the 0.01 level (2-tailed).

Table: 7.0 


\begin{tabular}{|c|c|c|c|c|}
\hline \multicolumn{5}{|c|}{ Correlations } \\
\hline & & & Independent1 & Dependent \\
\hline \multirow{6}{*}{ Spearman's rho } & \multirow{3}{*}{ Independent 1} & Correlation Coefficient & 1.000 & $.351^{* *}$ \\
\hline & & Sig. (2-tailed) & & .000 \\
\hline & & $\mathrm{N}$ & 122 & 122 \\
\hline & \multirow{3}{*}{ Dependent } & Correlation Coefficient & $.351^{* *}$ & 1.000 \\
\hline & & Sig. (2-tailed) & .000 & \\
\hline & & $\mathrm{N}$ & 122 & 122 \\
\hline
\end{tabular}

**. Correlation is significant at the 0.01 level (2-tailed).

Table:7.1

Ambiance and Customer Satisfaction

\begin{tabular}{|rl|r|r|}
\hline \multicolumn{2}{|c|}{ Correlations } & \multicolumn{1}{c|}{ Dependent } \\
\hline \multirow{3}{*}{ Independent2 } & Pearson Correlation & 1 & $.577^{* *}$ \\
& Sig. (2-tailed) & & .000 \\
& $\mathrm{~N}$ & 122 & 122 \\
Dependent & Pearson Correlation & $.577^{* *}$ & 1 \\
& Sig. (2-tailed) & .000 & 122 \\
\hline
\end{tabular}

**. Correlation is significant at the 0.01 level (2-tailed).

Table: 8.0

Correlations

\begin{tabular}{|c|c|c|c|c|}
\hline & & & Independent 2 & Dependeambiancent \\
\hline \multirow{6}{*}{ Spearman's rho } & \multirow{3}{*}{ Independent 2} & Correlation Coefficient & 1.000 & $.605^{* *}$ \\
\hline & & Sig. (2-tailed) & & .000 \\
\hline & & $\mathrm{N}$ & 122 & 122 \\
\hline & \multirow{3}{*}{ Dependent } & Correlation Coefficient & $.605^{* *}$ & 1.000 \\
\hline & & Sig. (2-tailed) & .000 & \\
\hline & & $\mathrm{N}$ & 122 & 122 \\
\hline
\end{tabular}

**. Correlation is significant at the 0.01 level (2-tailed).

Table: 8.1

Pricing and Customer Satisfaction

\section{Correlations}

\begin{tabular}{|ll|r|r|}
\hline & & Independent3 & Dependent \\
\hline \multirow{3}{*}{ Independent3 } & Pearson Correlation & 1 & $.577^{* *}$ \\
& Sig. (2-tailed) & & .000 \\
& $\mathrm{~N}$ & 122 & 122 \\
& Pearson Correlation & $.577^{* *}$ & 1 \\
Dependent & Sig. (2-tailed) & .000 & 122 \\
& $\mathrm{~N}$ & 122 \\
\hline
\end{tabular}

**. Correlation is significant at the 0.01 level (2-tailed).

Table:9.0 


\begin{tabular}{|c|c|c|c|c|}
\hline \multicolumn{5}{|c|}{ Correlations } \\
\hline & & & Independent3 & Dependent \\
\hline \multirow{6}{*}{ Spearman's rho } & \multirow{3}{*}{ Independent3 } & Correlation Coefficient & 1.000 & $.558^{* *}$ \\
\hline & & Sig. (2-tailed) & & .000 \\
\hline & & $\mathrm{N}$ & 122 & 122 \\
\hline & \multirow{3}{*}{ Dependent } & Correlation Coefficient & $.558^{* *}$ & 1.000 \\
\hline & & Sig. (2-tailed) & .000 & \\
\hline & & $\mathrm{N}$ & 122 & 122 \\
\hline
\end{tabular}

**. Correlation is significant at the 0.01 level (2-tailed).

Table:9.1

Quality of Food and Customer Satisfaction

\begin{tabular}{|ll|r|r|}
\hline \multicolumn{2}{|c|}{ Correlations } & Independent4 & Dependent \\
\hline \multirow{3}{*}{ Independent4 } & Pearson Correlation & 1 & $.592^{* *}$ \\
& Sig. (2-tailed) & & .000 \\
& $\mathrm{~N}$ & 122 & 122 \\
Dependent & Pearson Correlation & $.592^{* *}$ & 1 \\
& Sig. (2-tailed) & .000 & 122 \\
& $\mathrm{~N}$ & 122 \\
\hline
\end{tabular}

**. Correlation is significant at the 0.01 level (2-tailed).

Table: 10.0

\section{Correlations}

\begin{tabular}{|lll|r|r|}
\hline & & Independent4 & \multicolumn{1}{c|}{ Dependent } \\
\hline & \multirow{3}{*}{ Independent4 } & Correlation Coefficient & 1.000 & $.588^{* *}$ \\
& & Sig. (2-tailed) &. & .000 \\
Spearman's rho & & $\mathrm{N}$ & 122 & 122 \\
& & Correlation Coefficient & $.588^{* *}$ & 1.000 \\
& \multirow{2}{*}{ Dependent } & Sig. (2-tailed) & .000 &. \\
& & $\mathrm{~N}$ & 122 & 122 \\
\hline
\end{tabular}

**. Correlation is significant at the 0.01 level (2-tailed).

Table:10.1

\section{Regression Analysis}

\begin{tabular}{|l|r|r|r|r|}
\hline Model & R & R Square & Adjusted R Square & Std. Error of the Estimate \\
\hline 1 & $.760^{\mathrm{a}}$ & .577 & .562 & 1.59116 \\
\hline
\end{tabular}

a. Predictors: (Constant), Independent4, Independent2, Independent1, Independent3 Table: 11.0

ANOVA $^{\mathrm{a}}$

\begin{tabular}{|rl|r|r|r|r|r|}
\hline Model & & Sum of Squares & \multicolumn{1}{|c|}{ df } & Mean Square & \multicolumn{1}{c|}{ F } & Sig. \\
\hline \multirow{2}{*}{1} & Regression & 403.984 & 4 & 100.996 & 39.891 & $.000^{\mathrm{b}}$ \\
& Residual & 296.221 & 117 & 2.532 & & \\
& Total & 700.205 & 121 & & & \\
\hline
\end{tabular}

a. Dependent Variable: Dependent

b. Predictors: (Constant), Independent4, Independent2, Independent1, Independent3

Table:11.1 


\section{Coefficients $^{\mathrm{a}}$}

\begin{tabular}{|l|r|r|r|r|r|}
\hline \multirow{2}{*}{ Model } & \multicolumn{2}{|c|}{ Unstandardized Coefficients } & Standardized Coefficients & \multirow{2}{*}{ Sig. } \\
\cline { 2 - 5 } & \multicolumn{1}{|c|}{$\mathrm{B}$} & Std. Error & Beta & \\
\hline (Constant) & 2.639 & 1.046 & 2.522 & .013 \\
Independent1 & -.024 & .064 & -.026 & -.370 & .712 \\
1 Independent2 & .309 & .055 & .392 & 5.669 & .000 \\
Independent3 & .253 & .055 & .327 & 4.592 & .000 \\
Independent4 & .288 & .074 & .291 & 3.901 & .000 \\
\hline
\end{tabular}

a. Dependent Variable: Dependent Table: 11.2 